\title{
TRENDS IN AIRPORT SURFACE ACCESS IN THE LONDON MULTI-AIRPORT SYSTEM
}

Richard Moxon ${ }^{1}$

Cranfield University

\begin{abstract}
The London multi-airport system is described and changes in ownership from state organisations to competing private enterprises are assessed. A taxonomy of United Kingdom government action related to airport planning policy is presented with critical analysis in relation to airport surface access strategy. Changes in public transport use by passengers and employees at London airports are quantified to illustrate the success or otherwise of government policy. Passenger groups (defined by nationality and trip purpose) driving the increase in public transport are identified. Current London airport surface access strategic targets for passengers and employees are compared with the early versions suggested by the government to highlight the changed airport approach. Emerging surface airport access issues at London's airports are discussed.
\end{abstract}

Key words: United Kingdom airport policy, airport surface access strategy, multi-airport systems, airport planning.

${ }^{1}$ Centre for Air Transport Management, Cranfield University, Bedfordshire, MK43 0TR, UK E: r.moxon@cranfield.ac.uk 


\section{INTRODUCTION}

London has moved from four government (national and local) owned airports before 1986 to the current market of six competing private enterprises designated as serving the capital. In parallel with this (since 1998) the United Kingdom government has chosen to publicise a variety of reports, guidance and policy relating to airport surface access. The regularity and detail of such publications has varied and they have not been mandatory in composition. In the last decade of numerous airport ownership changes in London, published research has not tracked the nature or the impact of government attempts to influence the move from private to public transport by airport employees and staff in the London multi-airport system.

This research aims to investigate trends in airport surface access at the London area airports since 1998. Objectives include: to identify individual airport surface access behaviour as a potential characteristic of the multi-airport system, to detail changes in airport ownership during this period, to produce a definitive classification of government action related to airport planning (critically assessed in relation to surface access) and to gauge the success of this intervention by quantifying changes in public transport use.

\section{METHODOLOGY}

Semi-structured interviews took place with senior operational and/or surface access managers at each of the London airports during 2014. Relevant literature relating to United Kingdom airports policy, airport surface access and multi-airport systems was reviewed. United Kingdom Civil Aviation Authority and London airport data and strategic documentation was gathered, adapted and interpreted.

\section{THE LONDON MULTI-AIRPORT SYSTEM}

There are now six facilities designated as 'London area airports' by the United Kingdom Civil Aviation Authority. They are shown in Figure 1 which also demonstrates their proximity to major roads (marked in yellow) and railways (marked in black) for surface access purposes.

The concept of the multi-airport system has been well documented in recent literature since around 2000. De Neufville defined a multi-airport system as a set of significant airports serving commercial air transport in a metropolitan area without regard to ownership or political control (United States of America. Federal Aviation Authority, 2000). The nature of the development of multi-airport systems was identified by Bonnefoy (2008) who noted that secondary airports in the system can emerge through construction of new facilities (London City) or through the emergence of an underutilised facility in the catchment area (London Southend). 
Figure 1: The London area airports

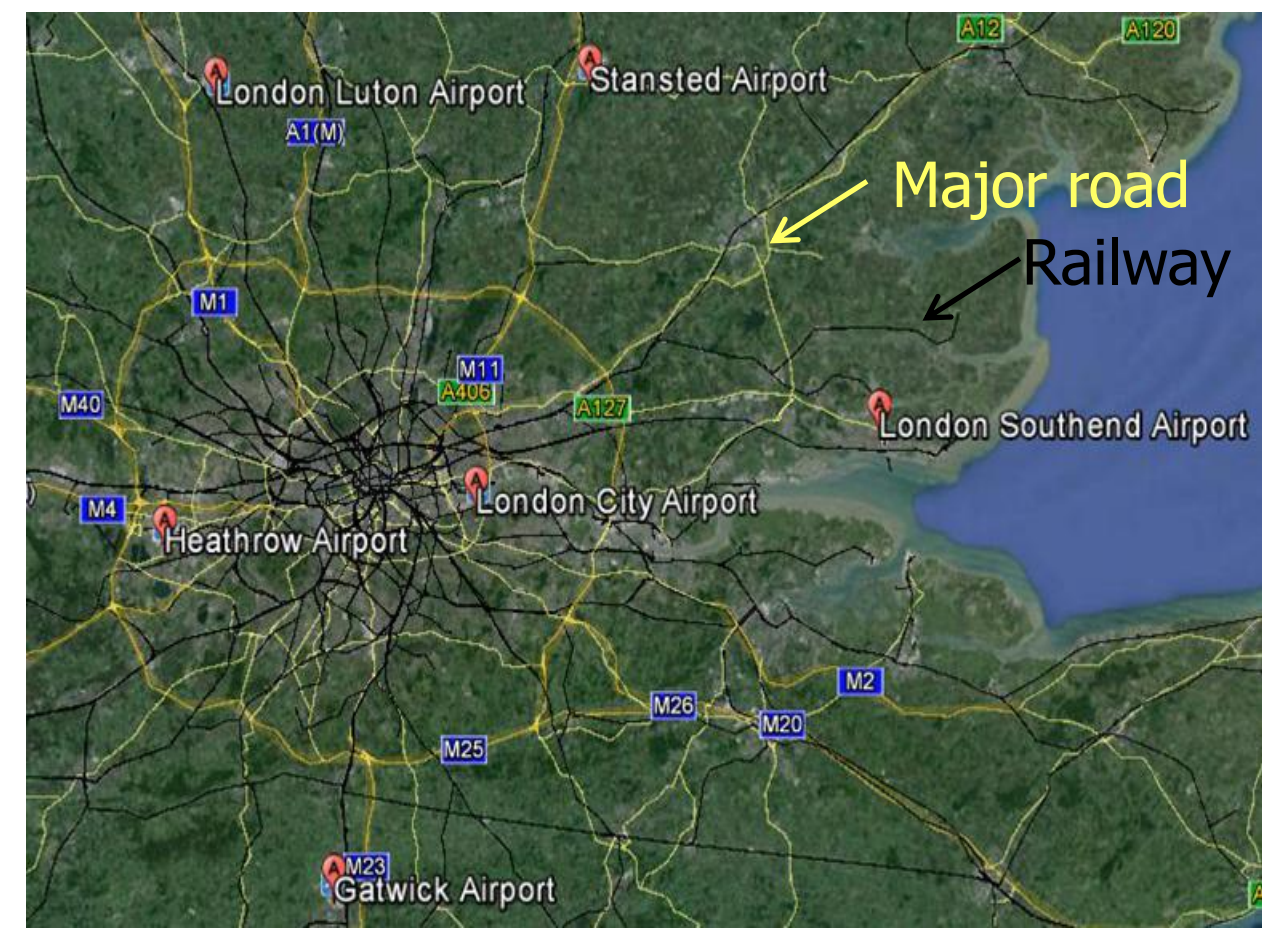

Source: Adapted from Google Earth (2014), UK Civil Aviation Authority (2014)

Passenger traffic handled by each of the London area airports since 1998 is shown in Figure 2. The annual passenger volumes show the marked negative impact of the economic crisis on passenger numbers at Heathrow, Gatwick and Stansted between 2008 and 2010. London Luton and London City demonstrated more resilience to traffic fluctuations during this time. Stansted still appears to be struggling to regain its lost share of the London market. The London area airports demonstrate typical multi-airport system characteristics identified by de Neufville and Odoni (2013). These include significantly differing levels of traffic and traffic specialisation (i.e. low cost carriers predominate at Stansted, London Luton and London Southend, network carriers at Heathrow whilst London City serves mainly short-haul business destinations). 
Figure 2: London area airport traffic 1998-2014 and transfer passenger proportion 2014

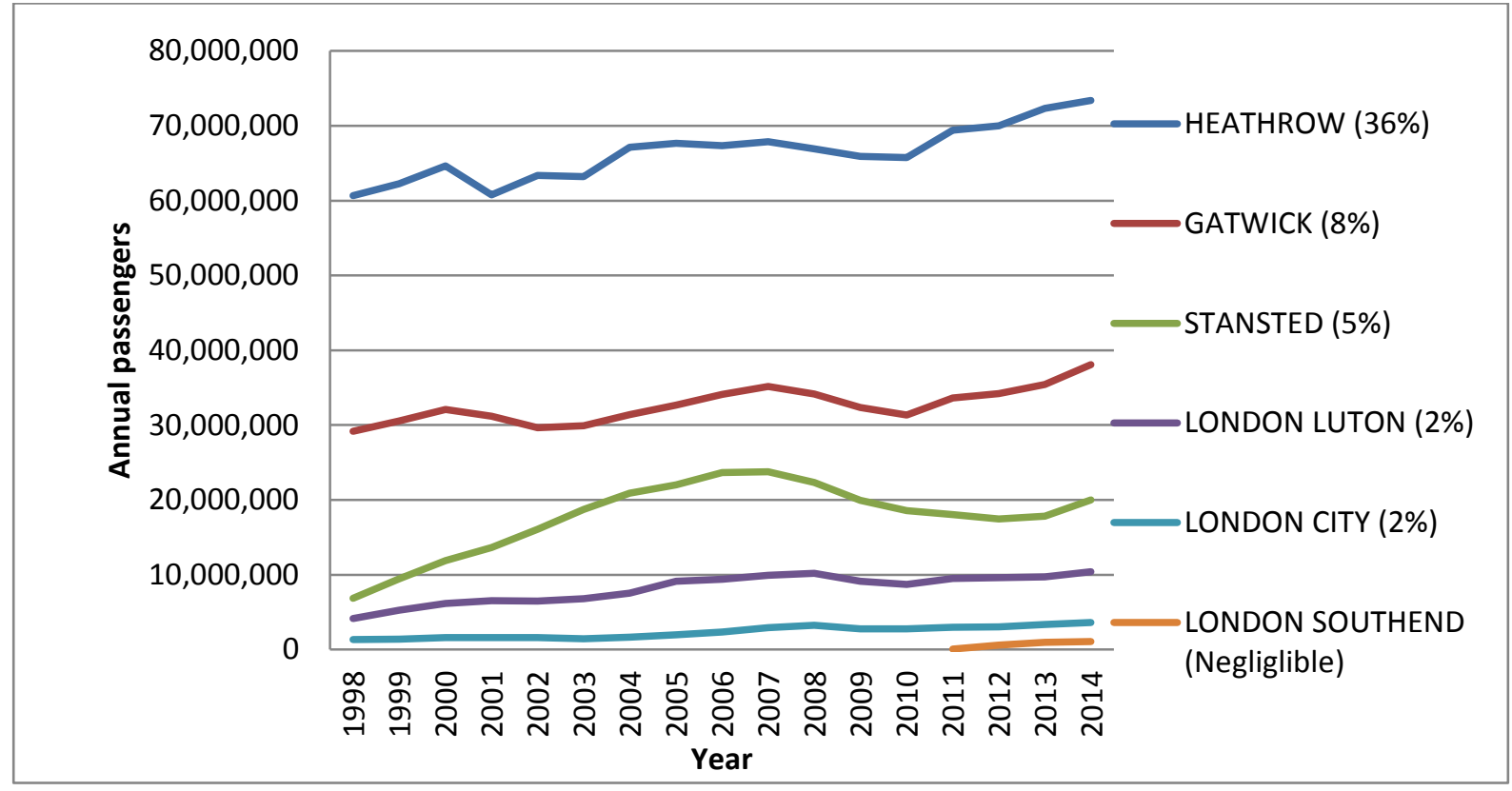

Source: Adapted from United Kingdom Civil Aviation Authority (2014) and London Southend Airport (2014)

Also, there are limitations in traffic allocation to the primary airport (because of capacity constraint at Heathrow). It can be argued that Gatwick acts as a second primary airport in the system and the similarity of traffic evolution between it and Heathrow support this view. No published research currently exists that examines multi-airport airport system characteristics in relation to passenger and employee surface access behaviour.

The proportion of passengers transferring between aircraft at each airport is an important factor when considering airport surface access. This is because only those passengers who start or end their journeys in London will use a surface mode of transport to get to or from the airport. The proportion of transfer passengers (arriving and leaving by air) varies greatly between the London airports and ranges from $36 \%$ at Heathrow to a negligible volume at London Southend. 


\section{FROM STATE OWNERSHIP TO COMPETING PRIVATE ENTERPRISES IN THE LONDON MULTI-AIRPORT SYSTEM.}

In 1986, an act of the United Kingdom's parliament mandated the dissolution of the government owned British Airports Authority (operator of seven United Kingdom airports including Heathrow, Gatwick and Stansted that all served London). This resulted in the creation of three separate London airport limited companies, each subsidiaries of the newly created BAA plc. Shares in BAA were then freely traded on the London Stock Exchange (Great Britain (a). The Airports Act, 1986). The act also required that UK airports in the ownership of local authorities with a turnover of more than one million pounds in two of the previous three years moved from direct local authority ownership and operation to airport companies. In the London multi-airport system, this meant that Southend and Luton airports were transferred to limited companies whose shares were initially held wholly by Southend Borough Council and Luton Borough Council respectively.

The result of the act was that the now privately owned Heathrow, Gatwick and Stansted airports had to survive without further subsidy from the United Kingdom government. It also meant that Southend and Luton airports were able to access private capital and move to private ownership if required because their local authority shareholders had the right to sell their shares to private companies (Humphreys, 1999).

The renamed London Southend airport is now leased and operated by the Stobart Group. Southend Borough Council sold the 150 year lease to Regional Airports Ltd. in 1994 which was then bought by the Stobart Group in 2008.

Whilst the rebranded London Luton airport has remained in the ownership of Luton Borough Council, it is operated, managed and developed by a private consortium under a public private partnership. In 2001, TBI plc (an airport operating company) became the majority shareholder and this company was in turn taken over by Abertis in 2005. The airport was then bought by Aena (the world's largest airport operator) in 2013.

London City airport began operations in 1988 on a former dock site in east London. It was constructed and wholly owned by John Mowlem and co. plc - a civil engineering company - and sold to Dermott Desmond (an Irish businessman) in 1995. It was then acquired in 2006 by a consortium seventy five per cent owned by Global Infrastructure Partners, a multi-national private equity firm specialising in infrastructure investment. 
A consortium led by the Ferrovial group (a Spanish company investing in transportation infrastructure) successfully bid for BAA plc in 2006 when the company was de-listed from the London Stock Exchange. The United Kingdom government's Competition Commission subsequently ruled that there was a lack of competition at London's airports because of a BAA monopoly. This resulted in the forced sale of London Gatwick in 2009 to Global Infrastructure Partners and the forced sale of London Stansted in 2013 to the Manchester Airport Group.

\section{UNITED KINGDOM GOVERNMENT AIRPORT PLANNING POLICY AND GUIDANCE: SPORADIC INCLUSION OF AIRPORT SURFACE ACCESS STRATEGY.}

Between 1998 and 2014, a variety of airport planning related government reports, guidance documents, policies and laws were produced by the United Kingdom government. All but three of them covered airport surface access to a greater or lesser degree. All were applicable to the London multi-airport system and are shown in Table 1 with analysis of their content related to airport surface access and public transport use detailed in the following text.

The United Kingdom government published a white paper (a document that details preferred future policy) in 1998. Entitled 'A new deal for transport: better for everyone', it described a new approach for an integrated transport strategy to tackle the growing challenges of domestic congestion and pollution (Great Britain (b). Department of the Environment, Transport and the Regions, 1998).

In relation to airport surface access, the government's aspiration was an improvement at the local level for staff and passengers using public transport. Initiatives were to be implemented and funded by the airports themselves. The government required specifically that, 'all airports in England with scheduled passenger services should lead an Airport Transport Forum...which should have three specific objectives:

- to draw up and agree challenging short and long term targets for increasing the proportion of journeys to the airport made by public transport.

- to devise a strategy for achieving those targets, drawing on the best practice available. This is likely to involve a wide range of measures to address the needs of all those travelling to airports. Bus and coach services should be included as well as rail. This means that the management of traffic on local and trunk roads will be an important issue for some airports.

-to oversee implementation of the strategy. Implementation should include green transport plans to cover commuting and business travel for all employees based at airports.' 
At a national and regional transport level in the 1998 document, the government also stated the importance of developing improved connection between airports and the public transport network, particularly for rail. In retrospect, it is striking that no specific mention was made of the now standard terminology of 'airport surface access strategy' or 'ASAS', although it is implied in the objectives noted for the Airport Transport Forums. Specific details of how to increase public transport use for airport journeys and what the strategy should look like were notably lacking whilst also requiring a strategy to be completed in 2000 .

Table 1: Timeline showing key airport planning related United Kingdom government actions impacting London airports 1998-2013

\begin{tabular}{|c|c|c|c|c|}
\hline $\begin{array}{l}\text { Year of } \\
\text { publication }\end{array}$ & Government Report & $\begin{array}{l}\text { Guidance } \\
\text { Document }\end{array}$ & $\begin{array}{l}\text { White Paper } \\
\text { (or policy document) }\end{array}$ & $\begin{array}{l}\text { Act of } \\
\text { Parliament } \\
\text { (or law) }\end{array}$ \\
\hline 1998 & & & $\begin{array}{l}\text { 'A new deal for } \\
\text { transport: better for } \\
\text { everyone' }\end{array}$ & \\
\hline 1999 & & $\begin{array}{l}\text { 'Guidance on airport } \\
\text { transport forums and } \\
\text { airport surface access } \\
\text { strategies' }\end{array}$ & & \\
\hline 2000 & & $\begin{array}{l}\text { 'Air transport forums } \\
\text { practice guide' }\end{array}$ & & \\
\hline 2003 & & & $\begin{array}{l}\text { 'The future of } \\
\text { air transport' }\end{array}$ & \\
\hline 2004 & & $\begin{array}{l}\text { 'Guidance on the } \\
\text { preparation of } \\
\text { masterplans' }\end{array}$ & & \\
\hline 2006 & $\begin{array}{l}\text { 'Air transport white paper } \\
\text { progress report' } \\
\text { 'The Stern review'* } \\
\text { 'The Eddington } \\
\text { transport study' }\end{array}$ & & & $\begin{array}{l}\text { 'The Airports } \\
\text { Act'* }\end{array}$ \\
\hline
\end{tabular}




\begin{tabular}{|l|l|l|l|l|}
\hline 2012 & & & & $\begin{array}{l}\text { 'The Civil } \\
\text { Aviation Act'* }\end{array}$ \\
\hline 2013 & $\begin{array}{l}\text { 'Airports Commission: } \\
\text { Interim report' }\end{array}$ & $\begin{array}{l}\text { 'Aviation policy } \\
\text { framework' }\end{array}$ & \\
\hline
\end{tabular}

$*=$ No reference to airport surface access

This problem was partly addressed in the following year by the government in response to airport feedback. 'Guidance on Airport Transport Forums and Airport Surface Access Strategies' contained the advice required for airport operators to devise targets to increase the proportion of staff and employees using public transport at airports and to create strategies to achieve them. It referred to the minimum strategy requirements being that targets 'should be realistic and deliverable'. Characteristics of a good strategy were noted as 'a set of performance indicators and other output measures which can be used to assess whether the strategy is delivering its stated objectives and targets'. More details of the recommended composition of an Airport Transport Forum were given, along with a clear statement that strategy targets are not statutory. Airport surface access strategies and specific measures to achieve them would not be prescribed by the government although some suggestions were provided (Great Britain (c). Department of the Environment, Transport and the Regions, 1999).

Further, less formal direction was provided in additional governmental guidance published in 2000. 'Airport transport forums good practice guide' gave further advice and cases of lessons learnt to date in the provision of Airport Surface Access Strategies in the United Kingdom (Great Britain (d). Department of the Environment, Transport and the Regions, 2000). In the case of the London multi-airport system these examples included Heathrow surcharging public and staff parking to fund increased spending on improving public transport. Luton Airport Parkway railway station had been newly built with a frequent free shuttle bus connecting it to the terminal. Gatwick airport encouraged staff cycling with the introduction of cycle racks, showers and cycle paths. Stansted was subsidising staff travel, providing discounts of up to $70 \%$ for staff travelling to or from work who purchased a monthly or annual 'Airport Travelcard'. It must be noted that the majority of the examples of good practice quoted related to Heathrow.

To address the pressure from growing demand for air travel at United Kingdom airports and the constrained airport capacity in London, the government published another white paper in 2003. 'The Future of Air Transport' detailed the preferred national framework for air transport for the next thirty years. In relation to London airports, two new runways were proposed. A second runway 
should be provided at Stansted and a third at Heathrow. A second runway at Gatwick should be provided if the conditions (mainly environmental) for a third Heathrow runway could not be met.

The government also recognised the potential for passenger and air transport growth through further development at London City, London Southend and London Luton airports without new runways. Airport operators were expected to produce master plans taking account of recommended development proposals and 'any proposal for new airport capacity...must be accompanied by clear proposals on surface access.'

Once again, the requirement for airports to set up Air Transport Forums and produce an Airport Surface Access Strategy was reiterated (if more than one thousand passengers air transport movements were handled per annum). Short and long term targets for decreasing the proportion of airport journeys by car were required. Proposals from airports to increase the proportion of passenger and staff journeys by public transport were also expected (Great Britain (e). Department for Transport, 2003).

'Guidance on the preparation of Master Plans' was produced by the government in 2004. It responded to feedback from airports requesting clarification on the purpose, timetable and scope/content of the required documents. Surface access was addressed explicitly and it was noted that, 'the split between use of public and private transport by air passengers and those working at the airport will affect the scale of any new investment in surface access that is required to accompany proposed airport expansion'. The development of both short and long term airport surface access strategies in line with master plans to 2030 was required (Great Britain (f). Department for Transport, 2004).

A review of strategic development since the airport white paper of 2003 was published in the 'Air transport white paper progress report' of 2006. The government noted a 'positive start' by airports in developing surface access strategies. London Luton airport was highlighted as an example of best practice to date. It had increased the percentage of passengers travelling by public transport between 2003 and 2005 by 4\%. Airports were now required to produce airport surface access strategies with specific targets for increasing public transport modal share (Great Britain $(\mathrm{g})$. Department for Transport, 2006).

In 2006, a further act of Parliament, 'The Airports Act' (amongst other things) gave new powers to airports to curtail airport aircraft noise and emissions but made no mention of the environmental impact of airport surface access (Great Britain (h). The Airports Act, 2006). 
A similar omission is noticeable in the Stern Review Report of the same year. It was commissioned by the government to report on the economic impact of responding to the threat of climate change by moving to a low carbon economy. It recommended that any carbon consuming activity is priced to reflect its true cost to society and the environment. Whilst aviation policy is considered from the perspective of aircraft emissions, airport surface access is ignored (Great Britain (i). The Stern Report Review, 2006).

An additional government commissioned report was authored by Sir Rod Eddington (the outgoing chief executive of British Airways) in 2006. His remit was to advise on how United Kingdom productivity, stability and growth were affected by long-term transport policy. 'The Eddington Transport Study' makes many references to airports, with a special consideration of the potentially high magnitude of social and economic returns on investment in airport surface access (Great Britain (j). Department for Transport, (2006). Importantly, one of three strategic economic priorities highlighted for the country is good quality connections between urban areas and international airports.

Government policy or official guidance did not then significantly revisit airport planning until 2012 . The Civil Aviation Act of this year reformed the economic regulation of Heathrow, Stansted and Gatwick and increased the focus of the Civil Aviation Authority on passengers' interests at these airports. Whilst winter operational resilience was emphasised, the importance of airport surface access to the passengers' experience remained unmentioned (Great Britain (k). The Civil Aviation Act, 2012).

Also in 2012, the government set up the politically autonomous Airports Commission which would 'take a fresh and independent look at the UKs future air capacity needs'. The first interim report of the commission was published in 2013 and marked a turning point in setting out the nature, scale and timing of steps needed to maintain the UK's status as an international hub for aviation' (Great Britain (I). Airports Commission, 2013). The report noted that there is a clear case for one net additional runway in London...by 2030 ' and 'there is likely to be a demand case for a second additional runway by 2050 , or...earlier.'

Specifically in relation to London airport surface access, the Airports Commission recommended improvements to Gatwick Airport railway station in addition to enhanced road and rail access there. An upgraded rail link between London and Stansted was suggested as well as better rail access to Heathrow from the south and the provision of smart ticketing at all airport stations allowing access to all train services by cards containing microchips. A comprehensive strategy for motorway access to London Luton was also suggested. London airports wishing to promote the development of 
additional runways were invited to submit details of proposed airport surface access strategies to the commission to support them. The interim report concluded with the short listing of three runway expansion options for further consideration in the London multi-airport system - two at Heathrow and one at Gatwick. ${ }^{2}$

The 'Aviation Policy Framework', also promoted in 2013 noted that a decade had passed since the 2003 publication of the Air Transport White Paper. It did not mention that it was the current government (at the time) that chose to disregard the previous administration's recommendations contained within the original 2003 document (Great Britain (m). Department for Transport, (2013). However, it did summarise the current approach to aviation policy and significantly noted that this policy framework now replaced all previous guidance on airport transport forums, master plans and airport surface access strategies. Whilst the list is 'not prescriptive or exhaustive', surface access strategies should now 'include:

-analysis of existing surface access arrangements;

-targets for increasing the proportion of journeys made to the airport by public transport by passengers and employees; cycling and walking. There should be short- and long-term targets;

-consideration of whether freight road traffic can be reduced;

-consideration of how low carbon alternatives could be employed;

-short-term actions and longer-term proposals and policy measures to deliver on targets such as: -proposed infrastructure developments e.g. light rail;

-car/taxi sharing schemes;

-improved information provision on public transport, cycling and walking options;

-car park management;

-through-ticketing schemes;

-indication of the cost of any proposals;

-performance indicators for delivering on targets;

\footnotetext{
${ }^{2}$ The final report of the Airports Commission was published in 2015 during the review of this paper. The shortlisted schemes were: an extended existing runway at Heathrow, a new runway at Heathrow and a new runway at Gatwick. The Commission endorsed the provision of an additional runway to the north-west of Heathrow to provide additional capacity in the London multi-airport system. Each of three alternative short-listed schemes had been appraised in respect to surface access. The first stated surface access strategy objective was 'to maximise the number of passengers and workforce accessing the airport via sustainable modes of transport'. The surface access assessment concluded that all three proposed schemes had met this objective with similar levels of success. It noted that the Gatwick scheme forecast the highest public transport mode share but that the favoured Heathrow scheme expected to provide the greatest number of passengers switching to sustainable modes of transport (Great Britain (n). Airports Commission, 2013).
} 
-monitoring and assessment strategies (internal and external);

-green transport incentive schemes for employees.'

Evidence of the United Kingdom government's recognition of the need for airports to develop more robust surface access strategies for employees and passengers did not become apparent until 1998. In the subsequent years, ten government publications (including externally commissioned and inhouse reports, guidance documents, policy statements and laws) have been created in relation to airport planning, all of which relate to the London airports. Of these, three make no reference to airport surface access. The remaining seven indicate consistent government focus on airport surface access between 1998 and 2004. The following years saw the issue ignored until 2013, with the exception of the white paper progress report in 2006. Throughout this period, specific targets for the proportion of airport employees and passengers travelling by public transport have never been mandated.

\section{HOW SUCCESSFUL HAVE THE AIRPORTS BEEN IN SHIFTING PASSENGERS AND EMPLOYEES FROM PUBLIC TO PRIVATE TRANSPORT?}

A common theme was revealed in the review of government actions relating to airport planning strategies at London airports. This was the repeatedly stated requirement for the airports to facilitate a change in surface access modal choice from private to public transfer for both their passengers and employees. It is assumed by the United Kingdom Civil Aviation Authority that public transport includes rail (heavy, light and underground), bus (local stopping services including hotel buses) and coach (long distance and express bus services). Taxis are categorised as private transport. This is not the definition used by all of the London airports considered in their own communications and publications and this can lead to difficulties in meaningful comparison without further adaptation of data.

Figure 3 shows the passenger public transport use since 1998. All airports in the system are now easily reached by public transport. This data was collected by the United Kingdom Civil Aviation Authority using a common sampling methodology for all of the airports considered, with the exception of London Southend airport. London Southend provided data from passenger surveys undertaken in-house in 2013 as no government funded passenger surveys have taken place there.

Stansted airport had the highest proportion of passengers using public transport at the end of the trend analysis period. The opening of a new bus and coach station in in 2007 following the introduction in 2006 of three express coach companies competing on price, frequency, fleet and service quality drove this (Stansted Airport (a), 2014). The proportion of passengers using public transport at Stansted has consistently increased each year since 2006 with a notable decline in 
2014. There was an increase in public transport use every year following the changed ownership of 2006 which contrasts with a fall following further ownership change in 2013.

The ownership of London City changed in 2006 but this does not explain the step change in public transport use in the following four years. The opening of the Docklands Light Railway in the same year provided London City with a direct link to the London Underground train network. This followed the opening of the Jubilee Line Extension in late 1999 which operated close to the airport with a direct bus link. Both infrastructure developments resulted in a large shift of passengers to public transport at the airport. Government survey data has shown this trend somewhat reversed from 2010 which contradicts the airport's own survey results showing public transport being used by $60 \%$ of passengers in 2013 and 61\% in 2014 (London City Airport (a), 2014).

Figure 3: Passenger public transport use at London airports 1998-2014

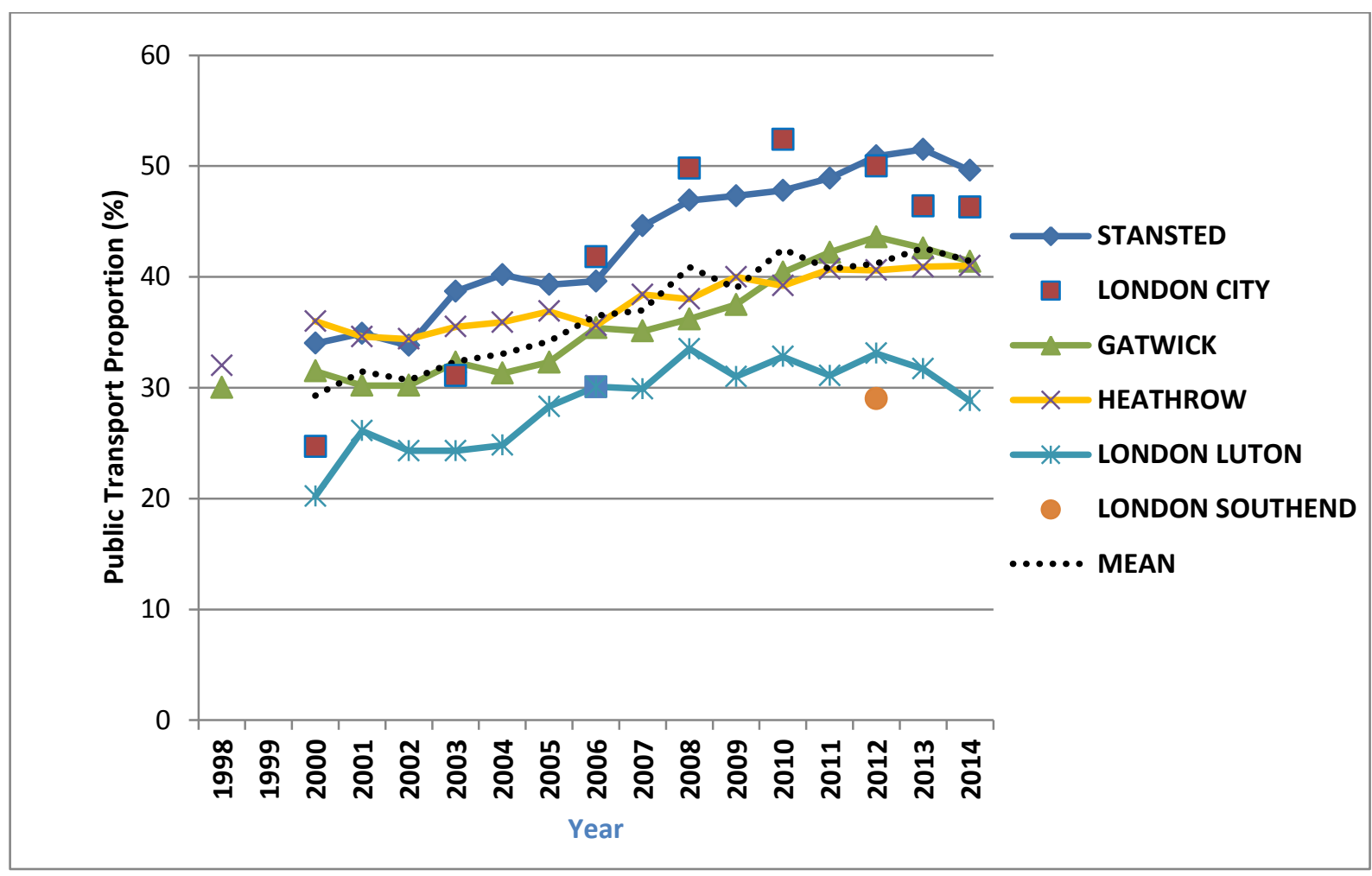

Source: United Kingdom Civil Aviation Authority (2014), London Southend airport (2014)

Public transport use by passengers grew consistently from 2003 to 2012 at Gatwick airport albeit with a minor stall in 2007. A recent proportional decline is visible in 2013 and 2014. Airport ownership changed in 2006 and 2009, the latest owners appearing to be more successful in shifting passengers to public transfer up to 2013. 
London Luton airport changed ownership in 2001, 2005 and 2013. It had the lowest proportion of passenger public transport use of all London airports in both 2000 and 2014, peaking in 2008 with the introduction of more frequent bus shuttle connections to Luton Airport Parkway railway station which originally opened in late 1999. The bus was provided by the train operating company First Group and ran every ten minutes to and from the airport from 05:00 to 00:00 (London Luton Airport, 2014). No trend growth is apparent beyond 2008 with oscillations around 32\% up to a clear reduction in public transport use in 2014 and little evidence of ownership change impacting public transport use.

London Southend's own survey shows public transport use in 2012 at $29 \%$ following the opening of a new dedicated airport railway station in 2011 developed by the new airport ownership of 2008 .

Following ownership change 2006, Heathrow airport saw growth in passenger public transport use to 2011 but little change since. The airport has not shown the marked recent shift away from public transport visible at Stansted, Gatwick and London Luton in 2014.

It is possibly useful to examine Figure 3 from the perspective of the characteristics of multi-airport systems discussed in section 3. The two primary airports in the system are Heathrow and Gatwick. It can be seen that the proportion of passengers using public transport at these two airports has consistently been close to the mean proportion for all airports in the system. Those airports designated as secondary airports in the system (Stansted, London City, London Luton and London Southend) show a much greater deviation from this mean - both higher and lower - with a more volatile trend.

Table 2 shows how absolute passenger numbers using public transport have increased between 2003 and 2014. This is overlooked in the literature and the industry and can yield surprising results. The airports have experienced volatile traffic growth over the period. Some have also seen marked changes in the proportion of transfer passengers who by definition do not use surface access as they both arrive and depart by aircraft. A good example is Stansted, where the transfer passenger proportion dropped by $8.7 \%$ between 2003 and 2014. This is because of the growing dominance of low cost carriers at the airport, with similar reductions at Gatwick and London Luton of $7.5 \%$ and $4.6 \%$ respectively.

By contrast, the transfer passenger rate remained steady at Heathrow and London City. The greatest increase in absolute passenger numbers using public transport was at Gatwick with 6.3 million more doing so in 2014 than in 2003 despite the airport not having the highest proportional shift. London City had the smallest absolute increase in passenger numbers using public transport even though it saw the greatest proportional modal shift; a result of its relatively small size. 
Table 2: Change in passenger public transport use 2003 to 2014 at London airports ${ }^{3}$

\begin{tabular}{|l|l|l|}
\hline & $\begin{array}{l}\text { Net passenger shift to } \\
\text { transport 2003-2014 (\%) }\end{array}$ & $\begin{array}{l}\text { Increase in annual passengers using } \\
\text { transport 2014 vs 2003 (M) }\end{array}$ \\
\hline STANSTED & 10.6 & 3.1 \\
\hline LONDON CITY & 14.5 & 1.2 \\
\hline GATWICK & 9.1 & 6.3 \\
\hline HEATHROW & 5.5 & 5.0 \\
\hline LONDON LUTON & 4.5 & 1.4 \\
\hline
\end{tabular}

Source: Adapted from United Kingdom Civil Aviation Authority (2014)

Airport access statistics were also analysed and adapted to assess if any particular passenger market segment was driving the shift towards increased public transport use. Nationality and trip purpose were considered as these are determined during government surveys at the airports. The four market segments were UK passengers on business trips, foreign (i.e. non-UK) passengers on business trips, UK passengers on leisure trips and foreign passengers on leisure trips. Table 3 shows for 2003 and 2014, the proportion of non-transfer passengers in each group and the proportion of passengers choosing to use public transport taken by each group. This is reported for each airport.

Thus the change in proportion of passengers in each market segment can be ascertained (e.g. the proportion of Gatwick non-transfer passengers who were UK nationals on a business trip fell from $11.2 \%$ in 2003 to $9.7 \%$ in 2014). Table 3 also shows the proportion of public transport users in each market group (e.g. $12.2 \%$ of public transport users were UK nationals on a business trip at Gatwick compared to $9.7 \%$ in 2014).

A significant contributor to the growth in public transport use at Gatwick and Heathrow has been the proportional increase in foreign leisure passengers at these airports and also this group's increased propensity to use public transport to travel to and from them.

${ }^{3}$ Excludes London Southend airport as no data available 
Table 3: Airport market segmentation and public transport use 2003 vs 2014

\begin{tabular}{|c|c|c|c|c|c|c|c|}
\hline \multirow[b]{2}{*}{ Airport } & \multirow[b]{2}{*}{$\begin{array}{c}\text { Nationality and } \\
\text { trip purpose }\end{array}$} & \multicolumn{2}{|c|}{2003} & \multicolumn{2}{|c|}{2014} & \multicolumn{2}{|c|}{ Change from 2003 to 2014} \\
\hline & & $\begin{array}{l}\text { Proportion } \\
\text { of non- } \\
\text { transfer } \\
\text { passengers } \\
(\%)\end{array}$ & $\begin{array}{c}\text { Proportion } \\
\text { of public } \\
\text { transport } \\
\text { users (\%) }\end{array}$ & $\begin{array}{c}\text { Proportion } \\
\text { of non- } \\
\text { transfer } \\
\text { passengers } \\
(\%)\end{array}$ & $\begin{array}{c}\text { Proportion } \\
\text { of public } \\
\text { transport } \\
\text { users (\%) }\end{array}$ & $\begin{array}{c}\text { Proportion of } \\
\text { non-transfer } \\
\text { passengers } \\
(\%)\end{array}$ & $\begin{array}{l}\text { Proportion of } \\
\text { public } \\
\text { transport users } \\
\text { (\%) }\end{array}$ \\
\hline \multirow{4}{*}{ Gatwick } & UK Business & 11.2 & 12.2 & 8.2 & 9.7 & -3.0 & -2.5 \\
\hline & UK Leisure & 70.3 & 54.2 & 65.3 & 45.7 & -5.0 & -8.5 \\
\hline & Foreign Business & 5.4 & 9.6 & 5.7 & 10.3 & 0.3 & 0.7 \\
\hline & Foreign Leisure & 13.1 & 24.0 & 20.7 & 34.3 & 7.6 & 10.3 \\
\hline \multirow{4}{*}{ Heathrow } & UK Business & 22.8 & 16.3 & 16.9 & 12.5 & -5.9 & -3.8 \\
\hline & UK Leisure & 34.3 & 34.8 & 37.7 & 30.5 & 3.4 & -4.3 \\
\hline & Foreign Business & 17.5 & 17.7 & 14.4 & 16.2 & -3.1 & -1.5 \\
\hline & Foreign Leisure & 25.4 & 31.1 & 30.9 & 38.5 & 5.5 & 7.4 \\
\hline \multirow{4}{*}{ London City } & UK Business & 37.5 & 29.6 & 26.2 & 26.7 & -11.3 & -2.9 \\
\hline & UK Leisure & 26.3 & 28.6 & 29.1 & 31.7 & 2.8 & 3.1 \\
\hline & Foreign Business & 22.1 & 19.5 & 26.0 & 20.5 & 3.9 & 1.0 \\
\hline & Foreign Leisure & 14.1 & 22.3 & 18.7 & 21.1 & 4.6 & -1.2 \\
\hline \multirow{4}{*}{ London Luton } & UK Business & 18.5 & 13.5 & 11.5 & 7.7 & -7.0 & -5.8 \\
\hline & UK Leisure & 61.6 & 49.2 & 65.5 & 55.3 & 3.9 & 6.1 \\
\hline & Foreign Business & 5.9 & 7.8 & 4.9 & 6.9 & -1.0 & -0.9 \\
\hline & Foreign Leisure & 14.0 & 29.6 & 18.1 & 30.1 & 4.1 & 0.5 \\
\hline \multirow{4}{*}{ Stansted } & UK Business & 12.2 & 8.8 & 8.7 & 5.8 & -3.5 & -3.0 \\
\hline & UK Leisure & 56.1 & 44.3 & 51.4 & 41.9 & -4.7 & -2.4 \\
\hline & Foreign Business & 4.5 & 5.7 & 6.2 & 8.1 & 1.7 & 2.4 \\
\hline & Foreign Leisure & 26.5 & 41.2 & 33.7 & 44.3 & 7.2 & 3.1 \\
\hline
\end{tabular}

Source: Adapted from United Kingdom Civil Aviation Authority (2014)

An increased proportion of UK leisure passengers using public transport is notable at London City and London Luton. At Stansted, the growth has come mainly from foreign passengers, both business and leisure passengers. This information could help the airports understand where to focus their surface access product developments and marketing to encourage public transport use in targeted groups.

Trends in employee public transport use are shown in Figure 4. All airports use their own methodologies for ascertaining this data thus comparison between airports is less robust than for passengers. Surveys generally take place sporadically thus trend analysis is harder. Only, Heathrow and London Luton report consistent growth in the proportion of employees using public transport. 
Figure 4: Employee public transport use at London airports 1997 to 2013 with current approximate airport employee numbers.

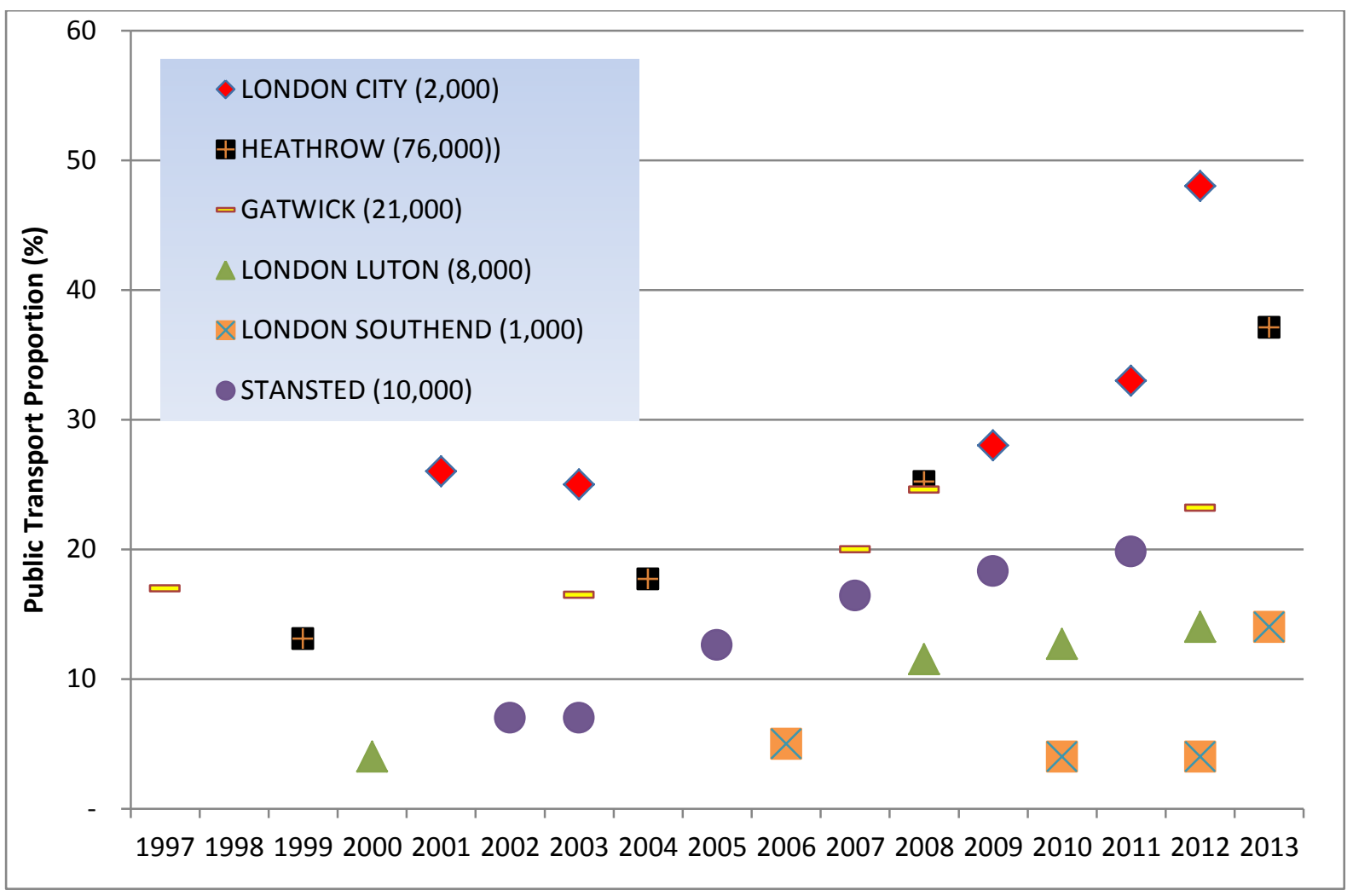

Source: Airports (2014)

Conclusions regarding further characteristics of the multi-airport system are harder to draw for employees than passengers when considering airport surface access. Again, the secondary airports show much greater deviation and volatility in the annual proportion of employees using public transport than at Heathrow and Gatwick (the primary airports). As the airports do not conduct surveys every year no mean is calculated for the system.

Heathrow, Gatwick and Stansted airports all offer staff subsidies to reduce the cost of commuting by train, bus and coach. In addition, Heathrow fund free local bus travel (available to all bus users, not just airport workers) to discourage short car journeys around the airport perimeter. London Southend's employees have access to discounts on some local buses but awareness and take up remains low. London City does not subsidise employee use of public transport. London City claims the highest proportion of staff using public transport at $48 \%$ in 2012 but it should be noted that passenger use was overestimated compared to government data. Heathrow and London Luton show linear growth. London Southend and London Luton have the lowest proportion of employees using public transport at $14 \%$ each. Employee numbers suggest that the smaller airports like 
London City and London Southend show the greatest range in employee public transport use with the larger airports grouped within this range.

\section{CURRENT AND PREVIOUS TARGETS FOR PUBLIC TRANSPORT USE.}

All of the airports shared their current airport strategic access strategy targets for passengers and employees before, during or after interview. These are compared with those in place in 2003 as described by Humphreys and Ison. Table 4 shows passenger targets in 2003 and 2014.

Table 4: London airports passenger surface access targets 2003 and 2014

\begin{tabular}{|l|l|l|}
\hline & 2003 & 2014 \\
\hline LONDON CITY & $\begin{array}{l}\text { Encourage more local bus services } \\
\text { to divert into LCA }\end{array}$ & $70 \%$ public transport by 2023 \\
\hline GATWICK & $40 \%$ public transport by 2008 & $40 \%$ public transport by 40 mppa* \\
\hline HEATHROW & $40 \%$ public transport by end of 2007 & $>40 \%$ public transport by 2019 \\
\hline LONDON LUTON & $\begin{array}{l}30 \% \text { public transport (no target } \\
\text { year) }\end{array}$ & $40 \%$ public transport by 2017 \\
\hline STANSTED & $25 \%$ public transport by 2005 & $43 \%$ public transport by 35 mppa* \\
\hline LONDON SOUTHEND & No specific target & $\begin{array}{l}>\text { or }=20 \% \text { public transport by } 1.5 \\
\text { mppa* and } 25 \% \text { by } 2 \mathrm{mppa*}\end{array}$ \\
\hline
\end{tabular}

Source: Humpheys and Ison (2003), Airports (2014)

$*_{\mathrm{mppa}}=$ millions of passengers per annum

All London airports now have specific and measurable targets in place for passenger public transport use. Humphreys et al. (2005) critically assessed the nature and practicality of the surface access targets then in place in the United Kingdom. London City has moved from a vague statement in 2003 to a target that may appear unattainable in comparison with their competitors. However, this airport classifies the black London taxi as public transport and by their own measure exceeded the target stated for 2023 by $2.3 \%$ in 2013 .

With hindsight, it is clear that Gatwick airport did not meet the stated target of 2003. The airport has also moved from a time bound target to traffic volume related one, which may or may not be more achievable depending on the accuracy of the airport's own forecasts. Heathrow's 2003 target was also not met and remains time bound and little changed in 2014. London Luton has introduced a time bound target whilst Stansted has also moved to a traffic volume related goal. London Southend gives two targets depending on the strength of continuation of recent rapid growth since becoming a base for the low cost carrier easyJet. 
The targets for employees are shown in Table 5 and demonstrate that all London airports have also moved to specific and measurable goals for employees between 2003 and 2014.

Table 5: London airports employee surface access targets 2003 and 2014

\begin{tabular}{|l|l|l|}
\hline & 2003 & 2014 \\
\hline LONDON CITY & $\begin{array}{l}\text { Encourage more local bus services to } \\
\text { divert into LCA }\end{array}$ & $\begin{array}{l}40 \% \text { single occupancy private } \\
\text { vehicle by } 2023\end{array}$ \\
\hline GATWICK & $\begin{array}{l}12 \% \text { of staff living in Crawley/Horley** } \\
\text { use local bus. Double staff cyling by } 2008\end{array}$ & $\begin{array}{l}40 \% \text { public transport by } 40 \\
\text { mppa* }\end{array}$ \\
\hline HEATHROW & $\begin{array}{l}2.6 \% \text { staff cycling by } 2003.2000 \text { car } \\
\text { sharers with } 65 \% \text { actively sharing by } 2003\end{array}$ & $\begin{array}{l}<45 \% \text { single occupancy } \\
\text { private vehicle by } 2019\end{array}$ \\
\hline LONDON LUTON & $6 \%$ public transport (no target year) & $\begin{array}{l}<\text { or }=60 \% \text { single occupancy } \\
\text { private vehicle by } 2017\end{array}$ \\
\hline STANSTED & $\begin{array}{l}88 \% \text { arrive as car drivers by } 2003.25 \% \\
\text { arrive as car passengers by } 2004 . \\
\text { Double cycling by end of } 2003\end{array}$ & $\begin{array}{l}<\text { or }=70 \% \text { single occupancy } \\
\text { private vehicle by } 35 \text { mppa* }\end{array}$ \\
\hline $\begin{array}{l}\text { LONDON } \\
\text { SOUTHEND }\end{array}$ & No specific target & $\begin{array}{l}\text { Sustain < or }=65 \% \\
\text { staff single occupancy vehicle }\end{array}$ \\
\hline
\end{tabular}

Source: Humpheys and Ison (2003), Airports (2014)

${ }^{*}$ mppa $=$ millions of passengers per annum ${ }^{* *}$ Crawley/Horley are towns adjacent to Gatwick

Gatwick is now unique in London in both setting a public transport use target for employees linked to traffic volume and also having identical targets for all airport users. Only $24 \%$ of staff at Gatwick used public transport for work access in 2012 (Gatwick Airport, 2014) so 40\% seems an unrealistic target with traffic in 2014 at 38.1 million passengers. All of the other airports focus on the reduction of the use of single occupancy private vehicles by employees getting to and from their work and quote more realistic targets. London City's target is close to being already achieved as $41 \%$ of staff drove to work in 2013 and it would be surprising if none of them car shared (London City Airport, 2013). Heathrow had 51\% single car occupancy by staff in 2013 (Heathrow Airport (a), 2014) and a very successful car share scheme. For London Luton it was 66\% in 2012 (London Luton Airport, 2012) and 69\% at Stansted in 2013 (Stansted Airport (b), 2014). London Southend met its quoted target in 2013 with $61 \%$ of staff using single occupancy vehicles (London Southend Airport, 2013). 


\section{EMERGING SURFACE ACCESS ISSUES AT LONDON AIRPORTS}

Eight semi-structured interviews with each of the London airports explored current issues in surface access and several key themes emerged (Gatwick Airport, London City Airport (b), Heathrow Airport (b), London Luton Airport, Stansted Airport (a), London Southend Airport (2014)). Two interviews took place at both London Southend and London Luton. Interview questions can be found in Appendix A.

Walking and cycling are increasingly acknowledged by London airports as a desirable access mode for airport employees on environmental and staff wellbeing grounds. Current walking and cycle use amongst airport staff is shown in Figure 5. Smaller airports like London Southend, London City and London Luton are located very close to residential areas. This allows easy access by employees who are not then reliant on public transport and can access their workplace by walking or cycling without requiring access to a private vehicle. London City noted the value of local staff able to walk or cycle to work as a key contributor to operational resilience. They are less vulnerable to delay during bad weather or because of security alerts that impact other modes of transport. London Luton offer free maintenance and bicycle lights as well as discounted bicycle purchase for staff. Parking racks and showers for cyclists have been expanded. London City plan to further encourage local staff to walk and cycle to work with an imminent $£ 100,000$ investment to improve routes. Heathrow operate a 'cycle hub' providing cycle sales, repairs, secure storage and free buses to central terminals. More remote airports like Stansted are less attractive to walkers and cyclists because of longer travel times. The airport is aware that interfaces between airport and local authority roads can be unattractive to potential users from a road safety and personal security perspective. 
Figure 5: Current staff walking and cycling to work proportions at London airports

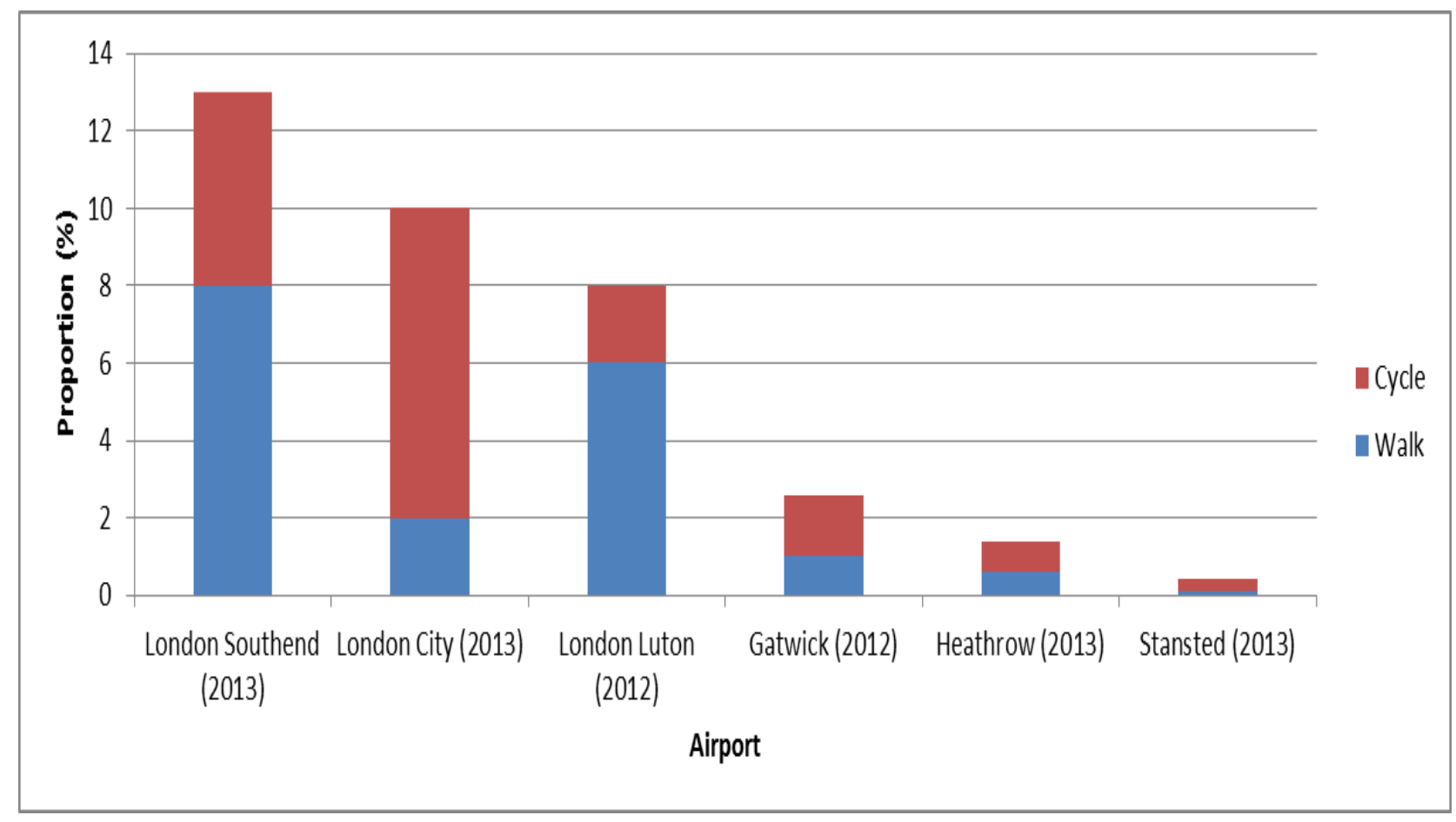

Source: Airports (2014)

Those airports with connections to main network railway lines serving multiple destinations paid particular attention to effective communication between train station and airport operational staff so as not to discourage train use. The availability of rail ticket purchasing opportunities and train information were maximised in the terminals. For example at Stansted, train tickets are for sale on board arriving aircraft during the journey, in airside arrivals routes from the aircraft as well as the baggage reclaim hall, landside arrivals and the train station. The objective is to raise train usage. Train information is also available in the landside arrivals hall and will soon be visible in the baggage reclaim halls and on the airport travel information smart phone application.

Concern was also raised about the generally inadequate provision of early and late trains. This precluded train use for employees who needed to be at work before and after flight operations as well as passengers unable to use public transport to connect with early flight departures and late flight arrivals. This has resulted in Gatwick, Stansted, London Southend and London Luton working with the train operating companies and the Department for Transport to try and enable the provision of services more suitable for use early and late in the day by both employees and passengers. 
A similar challenge is faced by London City and Heathrow with Transport for London services. Some specific examples were described. Whilst flight departures begin at Heathrow at 06:00, the first underground train does not leave central London until 05:12 (minimum 50 minute journey time) and the first Heathrow express train until 05:07 (15 minute journey time). At Stansted, the last flight arrival is at 23:50 and express train services to London cease at 00:30.

Ticket barriers required by some train operating companies at airport railway stations are unpopular with passengers (and airport surface access managers). There is a view that they may discourage train use for bigger groups and those with special needs or large amounts of luggage.

All of the London airports except London Gatwick have a headline target related to reducing the proportion of staff using single occupancy vehicles to get to work. Car sharing is actively promoted at Heathrow, the scheme being the largest in the world with 8000 members of which 2000 actively car share. A car share scheme is also promoted at Gatwick, Stansted and London Luton but surprisingly (given the nature of their targets) not at London City or London Southend. It was confirmed that informal employee car sharing takes place at these two airports.

Passenger drop-off and pick-up charges were introduced for private vehicles at the terminals of London Luton in 2009 and Stansted in 2012. The intent is to reduce private vehicle usage, reduce airport emissions and to increase revenue. Such charges have not been well received by passengers or airlines and remain a contentious issue with severe penalties for over-staying the standard drop-off or pick-up period. There is no evidence that the introduction of these charges has resulted in an increase in public transport use at these airports. No other London airport discussed plans to operate such a scheme although Heathrow later publicised the possibility of this.

\section{CONCLUSION}

United Kingdom government policy has repeatedly (albeit with some notable periods of silence) raised the issue of airport surface access strategy since the publication of the policy document 'A new deal for transport: better for everyone' in 1998. Guidance to airports now covers a much more detailed range of issues to cover and these were definitively stated in 'The aviation policy framework' of 2012. In parallel with this direction, the London airports have faced unprecedented changes in ownership, a continuing very public debate about London airport capacity and a volatile economic environment.

London airports have taken the guidance on board and all produce and regularly update their airport surface access strategies. All have been successful in decreasing the proportion of passengers and employees using private vehicles to access them although there have been varying 
degrees of success in evidence. Some of the early access targets were not met and this has perhaps resulted in a more pragmatic approach. A move is evident towards setting future passenger surface access targets that are related to a particular annual passenger volume at the airport, rather than a specific year. In the case of employees, the focus at London airports is now on targeting single occupancy private vehicles. This reflects the continuing lack of early and late bus, coach and train services at all London airports.

Future surface access issues highlighted for consideration in the London airports during this research are:

-Further reflection on methods of charging private vehicles to drop off and pick-up passengers.

-Investigation of methods to quantify and discourage the proportion of empty taxi journeys between London and the airports and vice versa. The nature of the concession arrangements at all London airports results in any taxi being allowed to drop passengers off at the airport but only a limited number of taxis being permitted to pick-up passengers (and being charged for this access).

-More ambitious targets for staff and passenger airport access as conditions of planning approval for airport expansion.

-Further recognition of the environmental (as well as the commercial) advantages of passenger parking as a substitute for passenger drop off and pick-up. 


\section{ACKNOWLEDGEMENT}

This work would not have been possible without the enthusiastic and honest approach of the London airports for which sincere gratitude is offered. Thanks also to the paper reviewers for detailed and constructive feedback on potential improvements.

\section{REFERENCES}

- $\quad$ Bonnefoy, P. (2008) Scalability of the air transportation system and development of multiairport systems: a world-wide perspective. PhD thesis. Massachusetts Institute of Technology.

- $\quad$ De Neufville, R. (2000) Planning multi-airport systems in metropolitan regions in the 1990s. Federal Aviation Authority, United States.

- $\quad$ De Neufville, R. and Odoni, A. (2013) Airport systems: planning, design and maintenance. $2^{\text {nd }}$ edn. New York City: McGraw-Hill.

- $\quad$ Gatwick Airport (2013) Your journey to work : staff travel plan 2013-2030.

- $\quad$ Gatwick Airport (2014) Interviewed by: Richard Moxon, $7^{\text {th }}$ April.

- Great Britain (a). The Airports Act 1986: Elizabeth II. Chapter 31 (1986) London: Her Majesty's Stationery Office. Available at: http://www.legislation.gov.uk/ukpga/1986/31/section/14 (Accessed 11th July 2014).

- $\quad$ Great Britain (b). Department of the Environment, Transport and the Regions (1998) A new deal for transport: better for everyone. London: The Stationery Office (Cm. 3950). Available at: http://webarchive.nationalarchives.gov.uk/+/http://www.dft.gov.uk/about/strategy/whitepapers/pr evious/anewdealfortransportbetterfo5695 (Accessed 12th July 2014).

- Great Britain (c). Department of the Environment, Transport and the Regions (1999) Guidance on airport transport forums and airport surface access strategies. London.

- Great Britain (d). Department of the Environment, Transport and the Regions (2000) Air transport forums good practice guide. London.

- Great Britain (e). Department for Transport (2003) The future of air transport. London: The Stationary Office (Cm. 6046). Available at: http://webarchive.nationalarchives.gov.uk/+/http:/www.dft.gov.uk/about/strategy/whitepapers/air/ executivesummary (Accessed 13th July 2014).

- Great Britain (f). Department for Transport (2004) Guidance on the preparation of airport master plans. London. Available at: http://webarchive.nationalarchives.gov.uk/20070110013802/http:/www.dft.gov.uk/pgr/strategy/whi tepapers/air/pwpa/guidanceonthepreparationofai5683 (Accessed 13th July 2014).

- $\quad$ Great Britain (g). Department for Transport (2006) Air transport white paper progress report. London. Available at: 
http://webarchive.nationalarchives.gov.uk/+/http:/www.dft.gov.uk/about/strategy/whitepapers/air/ executivesummary (Accessed 13th July 2014).

- Great Britain (h). The Airports Act 2006: Elizabeth II. Chapter 34 (2006) London: The Stationery Office. Available at: http://www.legislation.gov.uk/ukpga/2006/34/introduction/enacted (Accessed 14th July 2014).

- $\quad$ Great Britain (i). Department for Transport (2006) The Eddington Transport Study. London. Available at: http://webarchive.nationalarchives.gov.uk/+/http:/www.dft.gov.uk/about/strategy/transportstrateg y/eddingtonstudy/ (Accessed $14^{\text {th }}$ July 2014).

- Great Britain (j). Her Majesty's Treasury (2006) The Stern Review Report. London: The Stationary Office.

- Great Britain (k). The Civil Aviation Act 2012: Elizabeth II. Chapter 19 (2012) London: The Stationery Office. Available at: http://www.legislation.gov.uk/ukpga/2012/19/enacted (Accessed 15th July 2014).

- $\quad$ Great Britain (I). Airports Commission (2013) Airports Commission: Interim Report. London. Available at: https://www.gov.uk/government/publications/airports-commission-interim-report (Accessed 15th July 2014).

- Great Britain (m). Department for Transport (2013) Aviation policy framework. London: The Stationary Office (Cm. 8584). Available at: https://www.gov.uk/government/publications/aviationpolicy-framework (Accessed 15th July 2014).

- $\quad$ (Great Britain (n). Airports Commission, 2015) Airports Commission: Final Report. London. Available at: https://www.gov.uk/government/collections/airports-commission-final-report-andsupporting-documents\#final-report (Accessed $23^{\text {rd }}$ November 2015).

- $\quad$ Heathrow Airport (a) (2014) Sustainable transport plan 2014.

- $\quad$ Heathrow Airport (b) (2014) Interviewed by: Richard Moxon, $2^{\text {nd }}$ May.

- Humphreys, I. (1999) Privatisation and commercialisation: changes in UK airport ownership patterns. Journal of Transport Geography, 7 (1999), pp. 121-134.

- Humphreys, I. and Ison, S. (2003) Lessons from United Kingdom airports on ground control strategies. Transportation Research Record, 1850, pp.70-78.

- Humphreys, I., Ison, S., Francis, G., Aldridge, K. (2005) UK airport surface access targets, Journal of Air Transport Management, 11 (2005), pp. 117-124.

- London City Airport (2013) Draft surface access strategy. Available at: http://www.lcacc.org/access/draftASAS2013.pdf (Accessed 28th April 2014). 
- London City Airport (a) (2014) 2013 Section 106 annual performance. Available at: http://www.londoncityairport.com/content/pdf/LCY-Annual-Performance-Report-2014.pdf

- $\quad$ London City Airport (b) (2014) Interviewed by: Richard Moxon, $28^{\text {th }}$ April.

- $\quad$ London Luton Airport (2013) London Luton Airport 2012 staff travel survey report.

- $\quad$ London Luton Airport (2014) Interviewed by: Richard Moxon, 31 $31^{\text {st }}$ March.

- $\quad$ London Southend Airport (2013) 2013 Staff Travel Survey.

- $\quad$ London Southend Airport (2014) Interviewed by Richard Moxon, $11^{\text {th }}$ April.

- $\quad$ Stansted Airport (a) (2014) Interviewed by: Richard Moxon, $25^{\text {th }}$ April.

- $\quad$ Stansted Airport (b) (2014) Employer survey and employee travel survey analysis report.

- United States of America. Federal Aviation Authority (2000) Planning multi-airport systems in metropolitan regions in the 1990s. Washington D.C. 


\section{APPENDIX A : Semi-structured interview starter questions}

\section{Private vehicles}

How does private vehicle passenger pick-up / drop-off work at your airport?

What plans do you have to charge for private pick-up / drop-off?

What plans do you have to change the current arrangement for charging private vehicles?

What arrangements are in place for employee car sharing?

What incentives to you have to encourage employees to use public transport?

\section{Rail}

Is the airport station manned/monitored by airport or train company staff?

When do train tickets/information become available for arriving air passengers on their journey to the station from the aircraft?

What changes would you like to see in train operating times and why?

What concerns do you have about revenue protection barriers at the railway station?

\section{Taxis}

What is the nature of the airport concession with taxi operators?

How are taxi numbers managed at the airport?

How concerned are you about taxis operating empty in one direction between the airport and the city or vice versa?

\section{Data}

What additional historical data can you share regarding your airport's passenger and employee surface access behaviour?

How do you plan to develop the provision of airport surface access information to passengers?

\section{Bus and Coach}

What operational impact do bus/coach services have at the airport?

What future plans do you have regarding these services?

\section{Cycling and Walking}

How important is employee cycling and walking to/from work at the airport and why? 


\section{General}

What emerging issues would you like to highlight?

What explanations do you have regarding surface airport trends at your airport? 